\title{
PENGARUH DAYA TARIK IKLAN MOTIVASI KONSUMEN DAN KUALITAS PRODUK TERHADAP KEPUTUSAN PEMBELIAN MITSUBISHI PAJERO SPORT PADA PT. SUMATERA BERLIAN MOTOR RANTAUPRAPAT
}

\author{
Nurmayanti ${ }^{1}$, Abd. Rasyid Syamsuri ${ }^{2}$ \\ ${ }^{1}$ Alumni STIE Labuhanbatu \\ ${ }^{2}$ Dosen STIE Labuhanbatu
}

\begin{abstract}
ABSTRAK
Penelitian ini bertujuan untuk menganalisis faktor yang paling dominan dan mengetahui seberapa besar pengaruh daya tarik iklan, motivasi konsumen dan kualitas produk terhadap keputusan pembelian pada produk Mitsubishi Pajero Sport di Labuhanbatu. Sampel dalam penelitian ini adalah 50 responden.Teknik pengambilan sampel dalam penelitian ini dilakukan dengan teknik Purposive Sampling.Metode pengumpulan data menggunakan kuesioner. Teknik analisis yang digunakan adalah regresi berganda melalui perangkat lunak SPSS versi 16 dengan hasil yaitu: $\mathrm{Y}=0,618 \mathrm{X} 1+0,456 \mathrm{X} 2+0,579 \mathrm{X} 3+$ e. Berdasarkan analisis data statistik, indikator-indikatorpada penelitian ini bersifat valid dan variabelnya bersifat reliabel. Padapengujian asumsi klasik, model regresi bebas multikolonieritas, tidak terjadiheteroskedastisitas, dan terdistribusi secara normal.Urutan secara individu dari masing-masing variabel yang paling berpengaruhadalah variabel daya tarik iklan dengan koefisien regresi sebesar 0,618, lalu variabel motivasi konsumen dengan koefisien regresi sebesar 0,456 dan berpengaruh paling rendah.Sedangkan variabel kualitas produk dengan koefisien regresi sebesar 0,579. Model persamaan ini memiliki nilai $\mathrm{F}$ hitung sebesar 47,665 dan dengantingkat signifikansi 0,000. Dimana $\mathrm{F}$ hitung lebih besar dari $\mathrm{F}$ tabel $(3,20)$ dan dengantingkat signifikansi yang lebih kecil dari $\alpha(0,05)$. Hal tersebut menunjukan bahwavariabel independen dalam penelitian ini berpengaruh secara bersama-sama terhadapvariabel dependen yaitu keputusan pembelian.
\end{abstract}

Kata Kunci: Daya Tarik Iklan, Motivasi Konsumen, Kualitas Produk, Keputusan Pembelian. 


\section{PENDAHULUAN}

Dalam menghadapi persaingan pasar mendorong PT. Sumatera Berlian Motor untuk bertindak praktis dan ekonomis dalam usaha untuk menguasai pangsa pasar seluas mungkin.Hal ini karena pada dasarnya tujuan akhir dari penyampaian produk adalah konsumen, sedangkan kondisi konsumen saat ini sudah mulai sensitif dan mampu bertindak logis sehingga lebih selektif terhadap pembelian barang.

Untuk lebih memperluas pasar dan memperkenalkan produknya, Mitshubishi gencar melakukan kegiatan promosi untuk menarik minat beli konsumen.Salah satunya dengan membuat iklan melalui media cetak ataupun elektronik. Iklan yang dibuat didasari pada informasi tentang keunggulan dan keuntungan produk Mitsubishi khususnya produk terbaru mereka yaitu Pajero Sport, yang kemudian disusun sedemikian rupa sehingga menimbulkan ketertarikan pada calon konsumen yang melihat atau mendengarnya, dengan demikian iklan tersebut akan mempengaruhi perilaku pembelian konsumen terhadap produk mereka. Iklan yang disajikan harus mempunyai tema yang menarik, gambar yang bagus, serta Brand Endorser (Bintang Iklan) yang memiliki nilai jual tinggi dan sesuai dengan produk yang ditawarkan.

Dari iklan yang diterbitkan oleh PT. Sumatera Berlian Motors menjadikan penilaian tersendiri bagi konsumen yang secara langsung menimbulkan motivasi konsumen untuk memiliki produk Mitshubishi..Motivasi muncul karena ada kebutuhan yang dirasakan oleh konsumen.Kebutuhan sendiri muncul karena konsumen merasakan ketidaknyamanan antara yang seharusnya dirasakan dan yang sesungguhnya dirasakan. Motivasi ini juga muncul karena adanya faktorfaktor dari luar yang menimbulkan keharusan konsumen untuk memiliki produk.

Kualitas produk juga sangat berperan penting dalam membentuk kepuasan konsumen, selain itu juga erat kaitannya dalam menciptakan keuntungan bagi perusahaan. Semakin berkualitas produk yang diberikan oleh perusahaan maka kepuasan yang dirasakan oleh pelanggan akan semakin tinggi. Kualitas produk ialah produkyang sesuai dengan standar (target, sasaran atau persyaratan yang bisa didefinisikan, diobservasi dan diukur).Mengingat pendapatan masyarakat Indonesiayang sebagian besar menengah ke bawah, maka konsumen Indonesia rata-ratamenginginkan suatu produk yang berkualitas dengan harga yang terjangkau pintar dalam memilih produk mana yang berkualitas. Dalam hal ini apabila perusahaan inginmempertahankan keunggulan kompetitifnya dalam pasar, maka Mitsubishi harusmengerti aspek dimensi apa saja yang digunakan oleh konsumen untukmembedakan produk yang dijual perusahaan tersebut dengan produk pesaing.

Bermula dari adanya fenomena- fenomena berdasarkan penjelasan latar belakang diatas, seberapa besar pengaruh daya tarik iklan, motivasi konsumen dan kualitas produk dalam mempengaruhi konsumen untuk melakukan pembelian Mitshubishi Pajero Sport. Inilah yang membuat penulis ingin mengetahui secara lebih mendalam sehingga penulis memutuskan untuk melakukan penelitian dan mengambil judul PENGARUH DAYA TARIK IKLAN, MOTIVASI KONSUMEN DAN KUALITAS PRODUK TERHADAP KEPUTUSAN PEMBELIAN MITSUBISHI PAJERO SPORT PADA PT. 
SUMATERA BERLIAN MOTOR RANTAU PRAPAT (Studi Pada Konsumen Pembeli Mitsubishi Pajero Sport di Labuhanbatu).

\section{TINJAUAN PUSTAKA}

\section{Keputusan Pembelian}

Keputusan pembelian adalah tindakan dari konsumen untuk mau membeli atau tidak terhadap produk.Dari berbagai faktor yangmempengaruhi konsumen dalam melakukan pembelian suatu produk atau jasa, biasanya konsumen selalu mempertimbangkan kualitas, harga dan produk sudah yang sudah dikenal oleh masyarakat.Dalam keputusan pembelian, umumnya ada lima macam peranan yang dapat dilakukan seseorang. Kelima peran tersebut meliputi (Fandy Tjiptono, 2008):

1. Initiator; Orang yang pertama kali menyadari adanya keinginan atau kebutuhan yang belum terpenuhi dan mengusulkan ide untuk membeli suatu barang atau jasa tertentu.

2. Influencer; Orang yang memberi pandangan, nasihat, atau pendapat sehingga dapat membantu keputusan pembelian.

3. Decider; Orang yang menentukan keputusan pembelian, apakah jadi membeli, apa yang dibeli, bagaimana cara membeli, atau dimana membelinya.

4. Buyer; Orang yang melakukan pembelian secara aktual.

5. User; Orang yang mengkonsumsi atau menggunakan barang atau jasa yang telah dibeli.

\section{Daya Tarik Iklan}

Ralph S. Alexander dalam Jefkins (1997) merumuskan dengan Association Marketing Association (AMA), bahwa iklan menegaskan empat pokok batasan, yaitu; 1) penyajian gagasan terhadap barang, yaitu suatu bentuk iklan yang ditampilkan berdasarkan konsep produknya, 2) iklan ditujukan kepada kalayak, yaitu iklan dapat menjangkau masyarakat kelompok besar yang dipersempit menjadi kelompok pasar, 3) iklan mempunyai sponsor yang jelas, yaitu terciptanya iklan atas pemrakarsa perusahaan yang membiayainya, 4) iklan dikenai biaya penyajian, yaitu dalam penyebaran, penerbitan dan penayangan atasbiaya perusahaan.

Fungsi iklan dalam pemasaran di suatu perusahaan adalah memperkuat dorongan kebutuhan dan keinginan konsumen terhadap suatu produk untuk mencapai pemenuhan kepuasannya. Agar iklan berhasil merangsang tindakan pembeli oleh calon konsumen, menurut Pujiyanto (2008) setidaknya harus memenuhi kriteria AIDCDA yaitu: Attention : mengandung daya tarik, Interest : mengandung perhatian dan minat, Desire : memunculkan keinginan untuk mencoba atau memiliki, Conviction : menimbulkan keyakinan terhadap produk, Decision : menghasilkan kepuasan terhadap produk, Action : mengarah tindakan untuk membeli. Supaya mampu membujuk, mampu membangkitkan mempertahankan ingatan konsumen akan produk yang ditawarkan, maka perlu adanya daya tarik untuk keberhasilan komunikasi dengan konsumen.Menurut Kotler terdapat tiga tipe daya tarik yaitu:

a) Daya tarik pesan iklan rasional 
b) Daya tarik didasarkan perasaan dan emosi

c) Perencanaan Media

\section{Motivasi Konsumen}

Motivasi adalah kebutuhan yang cukup mampu mendorong seseorang bertindak (Kotler dan Keller,2009). Dalam bidang pemasaran motivasi pembelian adalah pertimbangan-pertimbangan dan pengaruh yang mendorong orang untuk melakukan pembelian (Sigit, 2009).Motivasi pembelian terbagi menjadi motivasi rasional dan emosional.Motivasi.Sedangkan motivasi emosional dalam pembelian berkaitan dengan perasaan, kesenangan yang dapat ditangkap oleh panca indera misalnya dengan memiliki suatu barang tertentu dapat meningkatkan status sosial, peranan merek menjadikan pembeli menunjukkan status ekonominya dan pada umumnya bersifat subyektif dan simbolik.Dari teori hirarki kebutuhan tersebut, oleh Maslow dikembangkan atas dasar tiga asumsi pokok, yaitu:

a. Manusia adalah makhluk yang selalu berkeinginan, dan keinginannya tidak selalu terpenuhi.

b. Kebutuhan yang sudah terpenuhi, tidak akan menjadi pendorong lagi.

c. Kebutuhan manusia tersusun menurut hirarki tingkat pentingnya kebutuhan.

Menurut Setiadi (2008) kebutuhan manusia oleh Maslow diklasifikasikan atas lima jenjang yang secara mutlak harus dipenuhi menurut tingkat jenjangnya. Masing-masing tingkat dijelaskan sebagai berikut:

a. Kebutuhan ini merupakan kebutuhan mempertahankan hidup dan bukti yang nyata akan tampak dalam pemenuhanya atas sandang, pangan, dan papan (Physiological Needs)

b. Manifestasinya dapat terlihat pada kebutuhan akan keamanan jiwa, keamanan harta, perlakuan yang adil, pensiun, dan jaminan hari tua (Safety Needs).

c. Kebutuhan sosial ini merupakan kebutuhan yang paling penting untuk diperhatikan segera setelah kebutuhan rasa aman dan kebutuhan psikologis sudah terpenuhi(Social Needs).

d. Kebutuhan ini lebih bersifat egoistik dan berkaitan erat dengan status seseorang. Semakin tinggi status seseorang maka akan semakin tinggi pula kebutuhannya akan pengakuan, penghormatan, prestise, dan lain-lain(Esteem Needs).

e. Kubutuhan jenis ini merupakan kebutuhan yang paling tinggi, yaitu untuk menunjukkan prestasinya yang maksimal tanpa terlalu menuntut imbalan dari organisasi. Motivasi yang ada pada diri konsumen akan mewujudkan suatu tingkah laku yang diarahkan pada tujuan yang mencapai sasaran kepuasan(Self-Actualization Needs).

\section{Kualitas Produk}

Menurut Schiffman dan Kanuk (1994) dalam Fandy Tjiptono (2008) menyatakan bahwa motivasi sebagai kekuatan dorongan dari dalam diri individu yang memaksa mereka untuk melakukan tindakan. Jika seseorang mempunyai motivasi yang tinggi terhadap obyek tertentu, maka dia akan terdorong untuk berperilaku menguasai produk tersebut. Sebaliknya jika motivasinya rendah, maka dia akan mencoba untuk menghindari obyek yang bersangkutan. Implikasinya dalam pemasaran adalah untuk kemungkinan orang tersebut 
berminat untuk membeli produk atau merek yang ditawarkan pemasaran atau tidak.Sejalan dengan hal tersebut keputusan pembelian dalam penelitian ini secara kontektual dapat dipengaruhi oleh karakteristik pribadi yaitu motivasi konsumen untuk membeli.Kualitas produk merupakan hal penting yang selanjutnya harus diusahakan oleh setiap perusahaan apabila menginginkan produk yang dihasilkan dapat bersaing di pasar.

Garvin (1998) telah mengungkapkan adanya delapan dimensi kualitasproduk yang bisa dimainkan oleh pemasar.

1. Dimensi performance atau kinerja produk

2. Dimensi reliability atau keterandalan produk

3. Dimensi feature atau fitur produk

4. Dimensi durability atau daya tahan

5. Dimensi conformance atau kesesuaian

6. Dimensi serviceability atau kemampuan diperbaiki

7. Dimensi aesthetic atau keindahan tampilan produk

8. Dimensi perceived quality atau kualitas yang dipersepsikan.

\section{METODE PENELITIAN}

\section{Populasi}

Populasi dalam penelitian ini adalah konsumen pengguna Mitsubishi Pajero Sport di Labuhanbatu.

\section{Sampel}

Teknik pengambilan sampel yang digunakan dalam penelitian ini adalah purposive sampling. Sampel penelitian ini yaitu pengguna Mitsubishi Pajero Sport di Labuhanbatu.Jumlah sampel dalam penelitian ini adalah 50 responden.Sampel yang diambil adalah yang peneliti temui di lapangan tanpa ada perencanaan pertemuan terlebih dahulu.

\section{Sumber Data}

Dalam penelitian ini yaitu data primer dan data sekunder. Dan adapun skala pengukuran yang digunakan adalah skala likert.

\section{Analisis Data}

\section{Analisis Regresi Linier Berganda}

Pada penelitian ini teknik analisis yang digunakan adalah regresi linier berganda untuk melihat pengaruh daya tarik iklan, motivasi konsumen dan kualitas produk terhadap keputusan pembelian Mitsubishi Pajero Sport pada PT. Sumatera Berlian Motors Rantauprapat. Berdasarkan dari analisa dengan program SPSS versi 16.0 maka diperoleh hasil regresi pada tabel sebagai berikut:

\section{Tabel 1}

\section{Hasil Analisis Regresi Berganda}




\section{Coefficients $^{\mathrm{a}}$}

\begin{tabular}{|l|c|c|c|c|c|}
\hline & $\begin{array}{c}\text { Unstandar } \\
\text { dized } \\
\text { Coefficien } \\
\text { ts }\end{array}$ & $\begin{array}{c}\text { Standardi } \\
\text { zed } \\
\text { Coefficie } \\
\text { nts }\end{array}$ & & \\
\cline { 2 - 4 } & $\begin{array}{c}\text { Std. } \\
\text { Erro } \\
\text { Model }\end{array}$ & Beta & $\mathrm{T}$ & Sig. \\
\hline 1 (Constant) & $\begin{array}{c}4.56 \\
0\end{array}$ & $\begin{array}{c}1.37 \\
4\end{array}$ & & 3.319 & .002 \\
$\begin{array}{l}\text { Dayatariiklan } \\
\text { Motivasikons } \\
\text { umen }\end{array}$ & .618 & .104 & .770 & 5.958 & .000 \\
$\begin{array}{l}\text { Kualitasprod } \\
\text { uk }\end{array}$ & .579 & .174 & .458 & 2.618 & .012 \\
\hline
\end{tabular}

a. Dependent Variable:

keputusanpembelian

\section{Sumber: Data Primer diolah, 2016}

Dari tabel diatas yang didapat berdasarkan analisis data dengan menggunakan program SPSS 16 for windowsmakadiketahui persamaan regresi linear berganda antara variabel independen dan variabel dependen sebagai berikut:

$$
\mathrm{Y}=4,560+0,618 \mathrm{X} 1+0,456 \mathrm{X} 2+0,579 \mathrm{X3}+\mathrm{e}
$$

Dari persamaan regresi di atas dapat disimpulkan bahwa :

1. Nilai konstanta sebesar 4,560 menunjukkan bahwa jika koefisien variabel dependen (Y), maka keputusan pembelian konsumen pada PT.Sumatera Berlian Motors hanya sebesar nilai konstanta yaitu sebesar 4,560.

2. Variabel daya tarik iklan (X1) berpengaruh secara positif terhadap keputusan pembelian dengan nilai koefisien sebesar 0,618. Artinya semakin besar daya tarik iklan yang ditampilkan tentang Mitsubishi Pajero Sport makasemakin besar pula pengaruhkonsumen untuk melihat dan melakukan pembelian sehingga keputusan pembelian juga akan meningkat.

3. Variabel motivasi konsumen (X2) berpengaruh secara positif terhadap keputusan pembelian dengan nilai koefisien sebesar 0,456. Artinya semakin besar motivasi konsumen yang didapat dari dalam maupun dari lingkup luar yang mempengaruhi untuk memiliki produk Mitsubishi sehingga keputusan pembelian produk juga akan meningkat.

4. Variabel kualitas produk (X3) berpengaruh secara positif terhadap keputusan pembelian dengan nilai koefisien sebesar 0,579. Artinya semakin bagus kualitas produk yang diberikan oleh Mitsubishi Pajero Sport, maka semakin tinggi pula pengaruh konsumen untuk melakukan pembelian. Sehingga keputusan pembelian produk juga akan meningkat. 


\section{Uji Koefisien Determinasi (R2)}

Koefisien determinasi digunakan untuk mengetahui sejauh mana kemampuan variabel independen dalam menjelaskan variabel dependen. Berdasarkan dari analisa dengan program SPSS versi 16.0 maka diperoleh hasil koefisien determinasi pada tabel sebagai berikut

\section{Tabel 2}

\section{Hasil Pengujian untuk Uji Koefisien Determinasi}

Model Summary ${ }^{b}$

\begin{tabular}{|c|c|c|c|c|}
\hline Model & $\mathrm{R}$ & $\begin{array}{c}\mathrm{R} \\
\text { Squar } \\
\mathrm{e}\end{array}$ & $\begin{array}{l}\text { Adjusted } \\
\text { R Square }\end{array}$ & \begin{tabular}{|c|} 
Std. \\
Error of \\
the \\
Estimat \\
$\mathrm{e}$
\end{tabular} \\
\hline 1 & $\begin{array}{r}.87 \\
0^{\mathrm{a}}\end{array}$ & .757 & .741 & .96698 \\
\hline
\end{tabular}

a. Predictors: (Constant),

kualitasproduk, dayatariiklan,

motivasikonsumen

b. Dependent Variable:

keputusanpembelian

\section{Sumber: Data primer diolah, 2016}

Berdasarkan tabel diatas dapat dilihat besar nilai Adjusted RSquare sebesar 0,741 hal ini berarti $74,1 \%$ yang mempengaruhi konsumen dalam melakukan keputusan pembelian Mitsubishi Pajero Sport pada PT.Sumatera Berlian Motors Rantauprapatdipengaruhi oleh variabel daya tarik iklan (X1), motivasi konsumen (X2) dan kualitas produk (X3) sedangkan sisanya sebesar $25,9 \%(100 \%-74,1 \%)$ dipengaruhi oleh variabel - variabel lain yang tidak diteliti dalam penelitian iniseperti citraperusahaan, karakteristik tenaga penjual, strategi promosi dan lain-lain.

\section{Uji Statistik T}

Uji - $\mathrm{t}$ digunakan untuk membuktikan pengaruh antara daya tarik iklan, motivasi konsumen dan kualitas produk terhadap keputusan pembelian Mitsubishi Pajero Sport secara parsial. Hasil uji - t dapat dilihat pada tabel berikut ini :

Tabel 3

Hasil Uji (T-test) 


\section{Coefficients $^{\mathrm{a}}$}

\begin{tabular}{|l|c|c|c|c|c|}
\hline & $\begin{array}{c}\text { Unstandar } \\
\text { dized } \\
\text { Coefficien } \\
\text { ts }\end{array}$ & $\begin{array}{c}\text { Standardi } \\
\text { zed } \\
\text { Coefficie } \\
\text { nts }\end{array}$ & & \\
\cline { 2 - 4 } & $\begin{array}{c}\text { Std. } \\
\text { Erro } \\
\text { Model }\end{array}$ & Beta & $\mathrm{T}$ & Sig. \\
\hline 1 (Constant) & $\begin{array}{c}4.56 \\
0\end{array}$ & $\begin{array}{c}1.37 \\
4\end{array}$ & & 3.319 & .002 \\
$\begin{array}{l}\text { Dayatariiklan } \\
\text { Motivasikons } \\
\text { umen }\end{array}$ & .618 & .104 & .770 & 5.958 & .000 \\
$\begin{array}{l}\text { Kualitasprod } \\
\text { uk }\end{array}$ & .579 & .174 & .458 & 2.618 & .012 \\
\hline
\end{tabular}

a. Dependent Variable:

keputusanpembelian

\section{Sumber: Data primer diolah, 2016}

Berdasarkan hasil pengujian Secara parsial (uji t) semua variabel bebas (daya tarik iklan, motivasi konsumen dan kualitas produk) dinyatakan mempengaruhi variabel dependennya (keputusan pembelian) secara signifikan. $\mathrm{T}$ tabel dilihat dengan derajat bebas $=\mathrm{n}-\mathrm{k}$. Sehingga derajat bebasnya adalah 47 (50-3). Oleh karena itu t yang dilakukan adalah uji dengan dua arah dengan sig.0,05 ( $\left.\mathrm{t}_{\text {tabel }}=2.012\right)$. Pernyataan tersebut dapat dijelaskan sebagai berikut :

a. Pengaruh Variabel Daya Tarik Iklan Terhadap Keputusan Pembelian

Nilai uji - $\mathrm{t}$ antara daya tarik iklan terhadap keputusan pembelian sebesar 5,958 dengan sig. 0,000 . Nilai sig. uji $-\mathrm{t}$ yang lebih kecil $(<)$ dari $\alpha=0,05$ menunjukkan diterimanya hipotesis yang menyatakan daya tarik iklan berpengaruh signifikan terhadap keputusan pembelian.

b. Pengaruh Variabel Motivasi Konsumen Terhadap Keputusan Pembelian

Nilai uji - $t$ antara motivasi konsumen terhadap keputusan pembelian sebesar 2,618 dengan sig. 0,012. Nilai sig. uji $-\mathrm{t}$ yang lebih kecil $(<)$ dari $\alpha=0,05$ menunjukkan diterimanya hipotesis yang menyatakan motivasi konsumen berpengaruh signifikan terhadap keputusan pembelian.

c. Pengaruh Variabel Kualitas Produk Terhadap Keputusan Pembelian

Nilai uji $-\mathrm{t}$ antara daya tarik iklan terhadap keputusan pembelian sebesar 3,561 dengan sig. 0,001. Nilai sig. uji $-\mathrm{t}$ yang lebih kecil $(<)$ dari $\alpha=0,05$ menunjukkan diterimanya hipotesis yang menyatakan kualitas produk berpengaruh signifikan terhadap keputusan pembelian.

\section{Uji Statistik F}


Uji-F digunakan untuk membuktikan pengaruh antara daya tarik iklan, motivasi konsumen dan kualitas produk terhadap keputusan pembelian Mitsubishi Pajero Sport secara simultan atau bersama-sama, Hasil uji-F dapat dilihat pada tabel sebagai berikut:

Tabel 4

Hasil Uji (F-test) ANOVA ${ }^{\text {b }}$

ANOVA ${ }^{b}$

\begin{tabular}{|l|r|c|c|c|c|}
\hline & $\begin{array}{c}\text { Sum } \\
\text { of } \\
\text { Squar } \\
\text { es }\end{array}$ & Df & $\begin{array}{c}\text { Mean } \\
\text { Squar } \\
\text { e }\end{array}$ & F & Sig. \\
\hline 1 Regressi & $\begin{array}{r}133.7 \\
\text { on }\end{array}$ & 3 & 44.56 & 47.6 & .000 \\
Residual & $\begin{array}{r}43.01 \\
\text { a }\end{array}$ & 46 & .935 & 65 & \\
Total & $\begin{array}{r}176.7 \\
20\end{array}$ & 49 & & & \\
\hline
\end{tabular}

a. Predictors: (Constant), kualitasproduk, dayatariiklan, motivasikonsumen

b. Dependent

Variable:

keputusanpembelian

\section{Sumber: Data primer diolah, 2016}

$\mathrm{F}_{\text {hitung }}$ digunakan untuk menguji apakah model persamaan $\mathrm{Y}=\mathrm{a}+\mathrm{b} 1 \mathrm{X} 1+$ $\mathrm{b} 2 \mathrm{X} 2+\mathrm{b} 3 \mathrm{X} 3+\mathrm{e}$ yang diajukan dapat diterima atau tidak. Caranya adalah dengan membandingkan $F_{\text {hitung }}$ tersebut dengan $F_{\text {tabel. }}$ Jika $F_{\text {hitung }}>F_{\text {tabel }}$ maka model diatas dapat diterima, tetapi jika $F_{\text {hitung }}<\mathrm{F}_{\text {tabel }}$ maka model tersebut ditolak. Pernyataan tersebut dapat dijelaskan sebagai berikut:

a. $\quad F_{\text {hitung }}=47,665$

b. $\quad F_{\text {tabel }}$ dapat dilihat pada $\alpha 0,05$ dengan derajat bebas pembilang $=(\mathrm{k}-1)=3$ $1=2$, derajat penyebut $=(n-k)=50-3=47$ maka $F_{\text {tabel }}=3,20$.

c. Oleh karena $F_{\text {hitung }}>F_{\text {tabel }}$ atau 47,665 $>3,20$, maka dapat disimpulkan bahwa model yang digunakan sudah tepat. Maka Ho ditolak dan Ha diterima. Penolakan Ho dibuktikan dengan hasil perhitungan bahwa disimpulkan variabel daya tarik iklan (X1), motivasi konsumen (X2) dan kualitas produk (X3) secara bersamaan mempengaruhi keputusan pembelian (Y) Mitsubishi Pajero Sport di Labuhanbatu khususnya.

\section{Interpretasi Hasil dan Pembahasan}

\section{Pengaruh Daya tarik Iklan Terhadap Keputusan Pembelian}

Daya tarik iklan berpengaruh positif dan signifikan terhadap keputusan pembelian Mitsubishi Pajero Sport pada PT.Sumatera Berlian Motor, hal ini 
dibuktikan dari uji - t sebesar 5,958 dengan sig. 0,000. Nilai sig. uji - $\mathrm{t}$ yang lebih kecil $(<)$ dari $\alpha=0,05$. Hipotesis pertama menyimpulkan bahwa semakin tinggi nilai daya tarik iklan maka akan meningkatkan minat beli konsumen. Penelitian ini membuktikan bahwa daya tarik iklan secara signifikan dan positif mempengaruhi minat beli. Artinya jika daya tarik iklan Mitsubishi Pajero Sport ditingkatkan dalam hal rasionalitas atau mampu menyampaikan manfaat dan kegunaan produk dengan visualisasi yang mudah dipahami, emosionalitas atau dapat mengendalikan emosi negatif atau positif yang mendorong seseorang untuk melakukan atau tidak melakukan sesuatu dan moralitas atau mampu menyampaikan pesan moral yang mendorong pemirsa untuk melakukan aksi sosial. maka akan mampu meningkatkan keputusan pembelian. Sehingga dapat disimpulkan hipotesis pertama dalam penelitian ini diterima.

\section{Pengaruh Motivasi Konsumen Terhadap Keputusan Pembelian}

Nilai uji $-\mathrm{t}$ antara motivasi konsumen terhadap keputusan pembelian sebesar 2,618 dengan sig. 0,012. Nilai sig. uji - t yang lebih kecil $(<)$ dari $\alpha=0,05$ menunjukkan diterimanya hipotesis yang menyatakan motivasi konsumen berpengaruh signifikan terhadap keputusan pembelian. Hasil pengujian ini bisa diartikan apabila semakin besar motivasi konsumen yang didapat dari dalam maupun dari lingkup luar yang mempengaruhi untuk memiliki produk Mitsubishi sehingga keputusan pembelian produk juga akan meningkat.

\section{Pengaruh Kualitas Produk Terhadap Keputusan Pembelian}

Nilai uji - $\mathrm{t}$ antara daya tarik iklan terhadap keputusan pembelian sebesar 3,561 dengan sig. 0,001 . Nilai sig. uji $-\mathrm{t}$ yang lebih kecil $(<)$ dari $\alpha=0,05$ menunjukkan diterimanya hipotesis yang menyatakan kualitas produk berpengaruh signifikan terhadap keputusan pembelian. Hasil pengujian ini bisa diartikan apabila semakin bagus kualitas produk yang diberikan oleh Mitsubishi Pajero Sport, maka semakin tinggi pula pengaruh konsumen untuk melakukan pembelian. Sehingga keputusan pembelian produk juga akan meningkat.

\section{KESIMPULAN}

\section{Kesimpulan}

Berdasarkan hasil penjelasan pada bab sebelumnya, adapun kesimpulan dari pengaruh daya tarik iklan, motivasi konsumen dan kualitas produk terhadap keputusan pembelian Mitsubishi Pajero Sport pada PT.Sumatera Berlian Motors adalah sebagai berikut:

1. Dari hasil penelitian dapat disimpulkan bahwa, daya tarik iklan, motivasi konsumen dan kualitas produk berpengaruh signifikan terhadap keputusan pembelian Mitsubishi Pajero Sport di Labuhanbatu.

2. Dari hasil uji - $\mathrm{t}$ daya tarik iklan (X1) didapat hasil t hitung sebesar 5,958 dengan sig. 0,000 . Nilai sig. uji $-\mathrm{t}$ yang lebih kecil $(<)$ dari $\alpha=0,05$ 
menunjukkan diterimanya hipotesis yang menyatakan daya tarik iklan berpengaruh signifikan terhadap keputusan pembelian.

3. Untuk variabel motivasi konsumen (X2) diketahui nilai t hitung sebesar 2,618 dengan sig. 0,012. Nilai sig. uji $-\mathrm{t}$ yang lebih kecil $(<)$ dari $\alpha=0,05$ menunjukkan diterimanya hipotesis yang menyatakan motivasi konsumen berpengaruh signifikan terhadap keputusan pembelian.

4. Untuk variabel kualitas produk (X3) t hitung didapat dengan nilai sebesar 3,561 dengan sig. 0,001. Nilai sig. uji $-\mathrm{t}$ yang lebih kecil $(<)$ dari $\alpha=0,05$ menunjukkan diterimanya hipotesis yang menyatakan kualitas produk berpengaruh signifikan terhadap keputusan pembelian.

5. Berdasarkan hasil uji determinasi dapat dilihat besar nilai Adjusted RSquare sebesar 0,741 hal ini berarti 74,1\% yang mempengaruhi konsumen dalam melakukan keputusan pembelian Mitsubishi Pajero Sport pada PT.Sumatera Berlian Motors Rantauprapatdipengaruhi oleh variabel daya tarik iklan (X1), motivasi konsumen (X2) dan kualitas produk (X3) sedangkan sisanya sebesar $25,9 \%(100 \%-74,1 \%)$ dipengaruhi oleh variabel - variabel lain yang tidak diteliti dalam penelitian iniseperti citraperusahaan, karakteristik tenaga penjual, strategi promosi dan lain-lain.

6. $F_{\text {hitung }}>\mathrm{F}_{\text {tabel }}$ atau 47,665 > 3,20, maka dapat disimpulkan bahwa model yang digunakan sudah tepat. Maka Ho ditolak dan Ha diterima. Penolakan Ho dibuktikan dengan hasil perhitungan bahwa disimpulkan variabel daya tarik iklan (X1), motivasi konsumen (X2) dan kualitas produk (X3) secara bersamaan mempengaruhi keputusan pembelian (Y) Mitsubishi Pajero Sport

\section{DAFTAR PUSTAKA}

Agung Nugroho. 2006. Strategi Jitu memilih metode statistic penelitian dengan SPSS.Yogyakarta:Gramedia.

Ghozali, Imam. 2005. Analisis Multivariate dengan Program SPSS. Semarang: Badan Penerbit Universitas Diponegoro.

Kasali, Rhenald. 2006 :Manajemen Periklanan Konsp dan Aplikasinya di Indonesia. Jakarta : PT Pustaka Utama Grafiti.

Rangkuti, Freddy. 2006. Riset Pemasaran. Jilid 1 edisi 3, penerbit Erlangga.

Shimp, Terence A. 2003. Periklanan Promosi Aspek Tambahan Komunikasi Pemasaran Terpadu. Erlangga. Jakarta.

Sugiyono. 2005. Metode Penelitian Bisnis. Cetakan Kedelapan. CV Alfabeta. Bandung.

Fandy Tjiptono. 2007. Manajemen Jasa. Edisi Keempat. Andi.Yogyakarta.

Aldaan Faikar Annafik. 2012. "Pengaruh Kualitas Produk, Harga dan Daya tarik Iklan Terhadap Keputusan Pembelian Sepeda Motor Yamaha”. Skripsi. Semarang: Fakultas Ekonomi Universitas Diponegoro. 
Nugroho J. Setiadi. 2008. Perilaku Konsumen: Konsep dan Implikasi (Untuk Strategi dan Penelitian Bisnis Pemasaran). Jakarta: Prenada Media.

Lupioadi, R.2006. Manajemen Pemasaran Jasa. Edisi 2. Salemba Empat. Jakarta Sugiyono. 2013. Metode Penelitian Bisnis (Pendekatan Kuantitatif, Kualitatif dan $R \& D)$. Edisi 8. Penerbit Alfabeta, Bandung.

Tjiptono, Fandy. 2008. Strategi Pemasaran. Edisi Ketiga. Bumi Aksara. Yogyakarta

Kotler, Philip. 1996. Manajemen Pemasaran: Analisis, Perencanaan,

Implementasi dan Pengendalian. Jakarta: Penerbit Erlangga

--------------- dan Gary Armstrong. 1997. Dasar-Dasar Pemasaran. Jakarta:

Prenhallindo

Jakarta:

Penerbit Erlangga

2006. Prinsip-Prinsip Pemasaran.Jilid 1.

Jakarata: Penerbit Erlangga

dan K. L. Keller. 2007. Manajemen Pemasaran. Jilid 1. Jakarta:

PT Index

Jakarta: PT Index

Handoko, T. Hani dan Swastha, Basu. 2006, Manajemen Pemasaran: Analisa PerilakuKonsumen, Edisi Pertama, Cetakan Ketiga, Penerbit BPFE, Yogyakarta.

Zeithaml V.A., (1988), Consumer Perception of Price, Quality and Value : A Means-EndModel and Synthesis of Evidence, Journal of Marketing, vol. 52.

Augusty,Ferdinand.2006.Metode Penelitian manajemen:Pedoman Penelitian untuk Skripsi,Tesis dan Disertai Ilmu Manajemen.Badan Penerbit Universitas Diponegoro:Semarang.

Schiftman,Leon,G and Kanuk, Leslie Lazar.1994.Cunsomer Behavior $8^{\text {th }}$ edition.Perarson Prentice Hall.

Rully Priamitra dan Drs. Sugiono M.Si.2010. "Pengaruh Motivasi Konsumen, Persepsi Kualitas Dan Sikap Konsumen Terhadap Keputusan Pembelian Toyota Avanza di Semarang.Skripsi. Semarang: Fakultas Ekonomi Universitas Diponegoro

http://www.datapenjualanMitsundo.com diakses 20 Januari 2016

http://www.keunggulanMisubishidanToyotaterbaru.com diakses 20 Januari 2016 Jakarta. 